\title{
Pandangan Aksiologi Terhadap Surrogate Mother
}

\author{
Mimi Halimah \\ Mahasiswa SPS S3 IPA UPI \& Dosen Prodi Pendidikan Biologi FKIP Unpas Bandung \\ Universitas Pendidikan Indonesia, Bandung \\ e-mail: mimi@unpas.ac.id
}

\begin{abstract}
Memiliki keturunan adalah impian untuk setiap pasangan yang sudah menikah, tetapi tidak bisa disangkal bahwa ada keadaan tertentu di mana seorang istri tidak dapat hamil karena kelainan di rahimnya atau ada faktor lain yang mebuat seorang istri tidak dapat hamil. Teknologi kedokteran telah menemukan solusi untuk pasangan yang mempunyai masalah sulitnya mendapatkan keturunan tersebut misalnya dengan inseminasi buatan atau dengan teknologi fertilisasi invitro yang dikenal dengan bayi tabung. Dalam perkembangannya program bayi tabung dapat dilakukan dengan menggunakan ibu pengganti atau dikenal dengan istilah Surrogate mother. Secara IImu kedokteran Praktik Surrogacy bisa dilakuan, bisa dijelaskan secara ilmiah dan memenuhi kaidah-kaidah kelmuan. Nmaun demikian segala sesuatu yang bisa dilakukan bukan berarti boleh secara etika, hukum dan aturan agama. Praktik Surrogacy pada kenyataannya banyak menimbulkan perdebatan dan kontroversi terutama ditinjau dari etika, hukum dan agama baik di Indonesia maupun negara lain. Meskipun ada juga beberapa negara yang membolehkan praktik ini seperti India, Thailand, Inggris, Amerika dan Australia. Praktik Surrogacy dalam Peraturan Hukum indonesia dilarang hal ini sesuai dengan pasal 16 UU No. 23 Tahun 1992 Tentang kesehatan dan Keputusan Menteri Kesehatan No. 72 / Menkes / Per / II / 1999 tentang Penyelenggaraan teknologi Reproduksi Buatan dan mengatur tentang hukum pelaksanaan bayi tabung. Praktik Surrogacy menurut tinjauan etika moral juga bertenatangan dengan nilai-nilai kemanusiaan bahkan menurut European Centre for Law and Justice tahun 2012 menyatakan bahwa Surrogate mother adalah kekerasan terhadap hak asasi manusia karena mengeksploitasi anak dan wanita, menjadikan mereka sebagai komoditi bisnis. Praktik Surrogacy juga dilarang secara tegas oleh berbagai ajaran agama seperti Islam, Kristen, katolik, Hindu dan Budha.
\end{abstract}

Keywords: Surrogate Mother, Surrogacy, Kedokteran, Etika, Hukum, Agama.

\section{Pendahuluan}

Memiliki keturunan adalah impian untuk setiap pasangan yang sudah menikah, tetapi tidak bisa disangkal bahwa ada keadaan tertentu di mana seorang istri tidak dapat hamil karena kelainan di rahimnya atau ada faktor lain yang membuat seorang istri tidak dapat hamil. Teknologi kedokteran telah menemukan solusi untuk pasangan yang mempunyai masalah sulitnya mendapatkan keturunan tersebut misalnya dengan inseminasi buatan atau dengan teknologi fertilisasi invitro yang dikenal dengan bayi tabung. Dalam perkembangannya program bayi tabung dapat dilakukan dengan menggunakan ibu pengganti atau dikenal dengan istilah Surrogate mother.

Ibu pengganti (Surrogate mother) adalah seorang wanita yang mengadakan perjanjian kehamilan (gestational agreement) dengan pasangan suami istri di mana wanita tersebut bersedia untuk hamil dari benih pasangan tidak subur dengan imbalan tertentu.

\section{Metode}

Metode yang digunakan dalam kajian ini adalah studi pustaka. Studi pustaka adalah kajian teori, referensi, serta literatur ilmiah lainnya yang berkaitan dengan bidaya, nilai dan norma yang berkembang pada situasi sosial yang diteliti (Sugiono, 2008). Studi pustaka dalam penelitian adalah metode pengumpulan data dengan mencari informasi lewat buku, majalah, koran, dan literatur lainnya yang bertujuan untuk membentuk sebah landasan teori (Arikunto, 2006). Tulisan ini mengetengahkan pembahasan mengenai pandangan aksiologi tentang surrogate mother. Aksiologi merupakan cabang filsafat ilmu yang mempertanyakan bagaimana manusia menggunakan ilmunya. Jadi yang ingin di capai oleh aksiologi adalah hakikat dan 
manfaat yang terdapat dalam suatu pengetahuan. Aksiologi berasal dari kata Yunani: axion (nilai) dan logos (teori), yang berarti teori tentang nilai. Aksiologi dipahami sebagai teori mengenai nilai sesuatu benda atau fenomena. Dalam aksiologi, ada dua penilain yang umum digunakan, yaitu etika dan estetika. Dengan demikian tulisan ini akan membahas mengenai tinjauan dan pandangan etika, moral dan hukum mengenai surrogate mother di berbagai negara dan berbagai agama.

\section{Hasil dan Pembahasan}

Ibu pengganti adalah seorang wanita yang setuju, biasanya dengan kontrak dan dengan bayaran, untuk melahirkan seorang anak untuk pasangan yang tidak memiliki anak karena istrinya tidak subur atau secara fisik tidak mampu membawa janin yang sedang berkembang. Seringkali ibu pengganti adalah ibu kandung anak, mengandung dengan cara inseminasi buatan dengan sperma dari suami. Pada ibu pengganti gestasional, istri subur tetapi tidak mampu membawa janin yang sedang tumbuh; anak dikandung melalui fertilisasi in vitro menggunakan telur istri dan sperma suaminya, dan embrio yang dihasilkan ditanam di rahim ibu pengganti (Febry,2013)

Dalam praktek yang dilakukan ada dua jenis sewa rahim tersebut yaitu :1) Sewa rahim semata (gestational surrogacy) Embrio yang lazimnya berasal dari sperma suami dan sel telur istri yang dipertemukan melalui teknologi IVF, ditanamkan dalam rahim perempuan yang disewa. 2) Sewa rahim dengan keikutsertaan sel telur (genetic surrogacy) Sel telur yang turut membentuk embrio adalah sel telur milik perempuan yang rahimnya disewa itu, sedangkan sperma adalah sperma suami. Walaupun pada perempuan pemilik rahim itu adalah juga pemilik sel telur, ia tetap harus menyerahkan anak yang dikandung dan dilahirkannya kepada suami istri yang menyewanya. Sebab, secara hukum, jika sudah ada perjanjian, ia bukanlah ibu dari bayi itu. Pertemuan sperma dan sel telur pada tipe kedua dapat melalui inseminasi buatan, dapat juga melalui persetubuhan antara suami dengan perempuan pemilik sel telur yang rahimnya disewa itu (Selian M.A.H, 2017).

Terdapat beberapa sebab yang akan menyebabkan sewa Rahim dilakukan, antaranya: 1) Seseorang wanita tidak mempunyai harapan untuk mengandung secara biasa kerana ditimpa penyakit atau kecacatan yang menghalangnya dari mengandung dan melahirkan anak; 2) Rahim wanita tersebut dibuang karena pembedahan; 3) Wanita tersebut ingin memiliki anak tetapi tidak mau memikul bebanan kehamilan, melahirkan dan menyusukan anak dan ingin menjaga kecantikan tubuh badannya dengan mengelakkan dari terkesan akibat kehamilan; 4) Wanita yang ingin memiliki anak tetapi telah putus haid (menopause); dan 5) Wanita yang ingin mencari pendapatan dengan menyewakan rahimnya kepada orang lain (Selian M.A.H, 2017).

Bentuk-bentuk sewa Rahim 1) Benih isteri (ovum) disenyawakan dengan benih suami (sperma), kemudian dimasukkan ke dalam rahim wanita lain. Kaedah ini digunakan dalam keadaan isteri memiliki benih yang baik, tetapi rahimnya dibuang karena pembedahan, kecacatan yang terus, akibat penyakit yang kronik atau sebab-sebab yang lain; 2) Sama dengan bentuk yang pertama, kecuali benih yang telah disenyawakan dibekukan dan dimasukkan ke dalam rahim ibu tumpang selepas kematian pasangan suami isteri itu; 3) Ovum isteri disenyawakan dengan sperma lelaki lain (bukan suaminya) dan dimasukkan ke dalam rahim wanita lain. Keadaan ini apabila suami mandul dan isteri ada halangan atau kecacatan pada rahimnya tetapi benih isteri dalam keadaan baik; 4) Sperma suami disenyawakan dengan ovum wanita lain, kemudian dimasukkan ke dalam rahim wanita lain. Keadaan ini berlaku apabila isteri ditimpa penyakit pada ovari dan rahimnya tidak mampu memikul tugas kehamilan, atau isteri telah mencapai tahap putus haid (menopause); dan Sperma suami dan ovum isteri disenyawakan, kemudian dimasukkan ke dalam rahim isteri yang lain dari suami yang sama. Dalam keadaan ini isteri yang lain sanggup mengandungkan anak suaminya dari isteri yang tidak boleh hamil (Selian M.A.H, 2017).

Proses dan pelaksanaan sewa rahim Proses pembuahan yang dilakukan di luar rahim oleh sepasang suami istri yang sah yang kemudian nanti akan di tanamkan di rahim wanita lain memerlukan ovum (sel telur) dan juga sperma. Ovum diambil dari tuba fallopi (kandung telur) seorang ibu dan sperma diambil dari ejakulasi seorang ayah. Sperma tersebut diperiksa terlebih dahulu apakah memenuhi persyaratan atau tidak. Begitu juga dengan sel telur seorang ibu, dokter berusaha menentukan dengan tepat saat ovulasi (bebasnya sel telur dari kandungan) dan memeriksa apakah terdapat sel telur yang masak atau tidak. Bila pada ovulasi terdapat selsel yang benar-benar masak, maka sel itu dihisap dengan sejenis jarum suntik melalui sayatan pada perut, sel itu kemudian diletakkan didalam tabung kimia dan di simpan di laboratorium yang diberi suhu menyamai panas badan seorang wanita agar sel telur tersebut tetap dalam 
keadaan hidup (Selian M.A.H, 2017). (1) Surrogate Mother Ditinjau Dari Segi Etika, Dalam perkembangan keilmuan, komisi etis diperlukan untuk mengendalikan perkembangan suatu imu dan teknologi supaya hasil perkembagan ilmu tersebut tidak merugikan manusia kelak kemudian hari dan hal inilah yang membedakan manusia dengan mahluk lain yaitu manusia memiliki akal dan nilai yang harus dijunjung tinggi.

Refleksi etis terhadap bayi tabung lahir setelah bayi tabung pertama lahir dan setelah sekian banyak penelitian mengenai bayi tabung berkembang pesat. Hal inilah yang mendasari diperlukannya pembahasan mengenai surrogate mother ditinjau dari segi etika. Menurut European Centre for Law and Justice tahun 2012 menyatakan bahwa praktik surrogacy adalah ekploitasi terhadap anak dan wanita. Hal ini dikarenakan akan merendahkan martabat anak dan perempuan karena menjadikan mereka sebagai objek kontrak dan komoditi. Tujuan surrogacy bukanlah kepentingan anak, tetapi untuk memenuhi keinginan orang dewasa. Selain itu bagi orang-orang yang tidak bertanggung jawab, praktik ini dijadikan kamuflase untuk human trafficking yaitu sengaja mengambil wanita-wanita muda untuk dijadikan komoditi surrogate mother dengan bayaran sedikit sedangkan bayaran dari orang tua pembawa benihnya sebenarnya lebih tinggi dari yang diberikan kepada surrogate mother nya. Bisnis inilah yang dimanfaatkan segelintir orang tidak bertanggung jawab dengan mengekplotasi wanita.

Praktik surrogacy ini juga dapat menimbulkan banyak masalah seperti kesulitan mengenai pembentukan filiasi dan kewarganegaraan anak, masalah dapat timbul dalam situasi jika kesehatan atau kehidupan ibu pengganti akan terancam selama kehamilan, jika ibu pengganti mengubah pikirannya dan ingin menjaga anaknya, , jika anak itu lahir dengan cacat dan orang tua pembawa benih tidak mau menerima kenyataan itu, atau Jika kecacatan terdeteksi selama kehamilan, dapatkah ibu pengganti bertanggung jawab menggugurkan? Belum lagi masalh jika yang melakukan parktik surrogacy ini adalh orang tua tungga yang mengambil sperma atau ovum dari donor. Masalah lain akan timbul jika pendonor tersebut meminta hak asuh atas anak tersebut, lebih jauh lagi jika pendonor tersebut memilki anak dari pasangannya yang lain dan anak keturunan mereka menikah karena sebelumnya tidak diketahui keturunannya maka akan terjadi incest (hubungan sedarah) incest ini secara genetika akan banyak menimbulkan masalah dengan munculnya kelainan-kelainan genetik pada keturunannya. Dan masalah-masalah lain yang akan timbul kelak kemudian hari.

Oleh sebab itu meskipun banyak perdebatan yang berkembang, praktik surrogacy di sebagian besar negara secara etika dan moral dilarang karena itu bertentangan dengan fitrah manusia sebagai mahluk yang berakal dan berbudi juga mahluk yang memiliki nilai dibandingkan dengan mahluk lainnya. Lebih lanjut lagi praktik surrogacy tidak sesuai dengan nilai-nilai kemanusiaan bahkan dalam European Centre for Law and Justice tahun 2012 menyatakan bahwa Surrogate motherhood: A Violation of Human Right, dan yang paling rentan dari praktek ini adalah adanya orang-oarang yang tidak bertanggung jawab memanfaatkan ketidakberuntungan sebagian orang dalam memiliki keturunan untuk mendapatkan keuntungan yang sebesar-besarnya tanpa mengindahkan nilai-nilai kemanusiaan.

Surrogate Mother Ditinjau Dari Segi Hukum, (a) Peraturan Hukum Di Indonesia, Peraturan hukum di Indonesia pasal 16 UU No. 23 Tahun 1992 Tentang kesehatan dan Keputusan Menteri Kesehatan No. 72 / Menkes / Per / II / 1999 tentang Penyelenggaraan teknologi Reproduksi Buatan dan mengatur tentang hukum pelaksanaan bayi tabung .Dalam peraturan tersebut jelas tersurat bahwa praktek surogate mother atau ibu pengganti dilarang di Idonesia . Bagi yang melanggar peraturan tersebut ada sangsi pidana yang diatur dalam pasal 82 UU No.23 Tahun 1992 tentang Kesehatan. Namun apabila terdapat pasangan suami istri indonesia yang melakukan praktek surogency di luar negri kemudian anaknya dibawa ke indonesia ini akan menimbulkan masalh karena bertentangan dengan hukum indonesia yaitu UU No. 1 Tahun 1974 tentang Perkawinan dimana dalam undang-undang tersebut tidak mengatur mengenai status anak yang lahir dari praktek surrogacy dan tidak mengatur juga jika terjadi konflik perbutan anak. Peraturan perunadng-undangan yang lebih baru yaitu dalam pasal 127 UU No. 36 Tahun 2009 tentang Kesehatan (“UU Kesehatan") diatur bahwa upaya kehamilan di luar cara alamiah hanya dapat dilakukan oleh pasangan suami istri yang sah dengan ketentuan : (a) Hasil pembuahan sperma dan ovum dari suami istri yang bersangkutan ditanamkan dalam Rahim istri dari mana ovum berasal, (b) Dilakukan oleh tenaga kesehatan yang mempunyai keahlian dan kewenangan untuk itu, (c) Pada fasilatas pelayanan kesehatan tertentu.

Adapun metode atau upaya kehamilan di luar cara alamiah selain yang diatur dalam pasal 127 UU Kesehatan, termasuk ibu pengganti atau sewa menyewa/penitipan rahim, secara hukum tidak dapat dilakukan di Indonesia. Sebagai informasi tambahan, praktek transfer embrio 
ke rahim titipan (bukan rahim istri yang memiliki ovum tersebut) telah difatwakan haram oleh Majelis Ulama Indonesia (MUI) pada 26 Mei 2006.

Peraturan Hukum Negara Lain, (1) Jerman, German Civil Code memberikan pengertian ibu sebagai wanita yang melahirkan bayi (Seorang lbu sebagai wanita yang melahirkannya). Selanjutnya ketentuan yang ada dalam tindakan perlindungan embrio menyatakan "Melarang transfer ke seorang wanita dari sel telur yang tidak dibuahi diproduksi oleh wanita lain serta fertilisasi buatan sel telur untuk tujuan apa pun selain membawa tentang kehamilan pada wanita dari siapa sel telur berasal. (2) Perancis, Perancis melarang dilakukannya praktik surrogacy bagi rakyatnya seperti yang diatur dalam KUHP perdata Perancis menyebutkan bahwa "Semua perjanjian yang berkaitan dengan prokreasi kehamilan pada pihak ketiga batal." Ketentuan lain tentang surrogacy bertentangan dengan prinsip yang tidak membolehkan komersialisasi tubuh manusia, dimana hal ini melibatkankan dalam kode Sipil bahwa "Hanya hal-hal dari sifat komersial dapat menjadi objek konvensi", (3) Switzerland, Surrogacy secara eksplisit dilarang berdasarkan Undang-Undang federal tentang reproduksi berbantuan. Konstitusi ini pada prinsipnya melarang Surrogate Mother seperti yang dinyatakan dalam Pasal 119 yaitu: Sumbangan embrio dan segala bentuk ibu pengganti adalah melanggar hukum.Selanjutnya bagi para pelaku yang terlibat dalam Surrogate Mother akan menerima hukuman seperti berikut:Siapa pun yang menggunakan teknik reproduksi berbantuan atau praktik Ibu pengganti akan dikenakan hukuman penjara atau denda dan hukuman yang sama akan berlaku bagi siapa saja yang bertindak sebagai perantara bagi praktik ibu pengganti. (4) Italia, Italia melarang dilakukannya prakktik Surogacy seperti yang diatur dalam ketentuan hukum tahun 2004 yang menyatakan bahwa "Semua kontrak ibu pengganti yang mengharuskan ibu pengganti untuk menyetujui penyerahan anak setelah kelahiran dan untuk memfasilitasi transfer hak asuh anak kepada pihak, tidak berlaku di bawah hukum sipil Italia, karena undang-undang memandang mereka sebagai kebijakan publik yang bertentangan". (5) Inggris, Inggris mengakui Surrogate Mother sejak tahun 1985 berdasarkan Surrogacy Arrangements Act 1985, dari ketentuan mengenai Surrogacy tersebut kemudian diperbaharui tahun 2008 melalui The human fertilization and embryologi act tahun 2008. (Judiasih, 2017). (6) Amerika Serikat, Hukum Praktek Surrogacy di Amerika Serikat memiliki perbedaan pada setiap negara bagian. Beberapa negara bagian melegalkan praktik ini seperti antara lain Alabama, Alaska, Arizona, Arkansas, Colorado, Georgia, Hawaii, Idaho, lowa, Kansas, Maine, Maryland, Minnesota, Missisipi, Missouri, Montana, Ohio, Pensylvania, Rhode Island, South Carolina, South Dakota, Tenesses, Vermont, Wisconsin, Wyoming. antara lain Alabama, Alaska, Arizona, Arkansas, Colorado, Georgia, Hawaii, Idaho, lowa, Kansas, Maine, Maryland, Minnesota, Missisipi, Missouri, Montana, Ohio, Pensylvania, Rhode Island, South Carolina, South Dakota, Tenesses, Vermont, Wisconsin, Wyoming. Sedangkan ada juga beberapa negara bagian yang tidak membolehkan praktik surrigacy dilakukan New York, Delaware, Indiana, Louisiana, Michigan, Nebraska, North Dakota, Washington DC. (7) Australia, Australia merupakan salh satu negara yang melegalkan Praktik Surrogacy dilakukan. Praktik ini diperbolehkan dengan beberapa ketentuan diantaranya boleh dilakukan oleh pasangan suami istri yang ingin memiliki keturunan namun tidak bisa mengandung secara alami dengan menyewa ibu pengganti. Apabila lbu pengganti ini berasal dari australia dan ibu pengganti ini bersedia tidak dibayar dengan maksud hanya murni menolong maka praktik ini dibolehkan. Sedangkan apabila tujuannya komersil maka praktik ini dilarang. Oleh sebab itu sebagian besar warga Australia yang ingin melakukan praktik Surrogacy, mereka melakukannya di luar negeri seperti thailand. (8) India, Sejak tahun 2002 India merupakan negara pertama yang melegalkan praktik Surrogacy secara komersial dilakukan. Dalam kurun waktu 10 tahun terakir india telah melahirkan kurang lebih 3000 bayi hasil praktik surrogacy. Kebanyakan bayi-bayi tersebut lahir dari orang tua pembawa benih yang berasal dari luar India. Praktik Surrogacy di India diatur dalam Assisted Reproductive Technology Regulation Bill 2010. Dalam peraturan tersebut pasangan suami istri atau orang tua tunggal yang ingin memiliki keturunan namun karena alsan kesehatan dan hal alinnya tidak bisa mengandung secara alami diperbolehkan melakukan praktik Surrogacy dengan syarat bersedia menanggung biaya selama proses kehamilan dan kelahiran. Namun untuk besarnnya tidak ditentukan nominalnya yang penting ada kesepakatan antara orang tua pembawa benih dan ibu pengganti yang akan mengandung anak tersebut. Selanjutnya Status hukum dari anak yang dilahirkan adalah sah anak dari orang tua pembawa benih. (9) Libya, Praktik Surrogacy dilarang secara tegas di Libya. Ketentuan ini di atur dalam perubahan hukum pidana Libya tertanggal 7 Desember 1972 yang menyatakan melarang segala bentuk inseminasi buatan termasuk didalmnya praktik Surrogacy. (10) Thailand, Thailand merupakan salah satu negara di 
asia yang memperbolehkan praktik Surrogacy dilakukan. Banyak warga Australia menggunakan jasa ibu pengganti dari wanita thailand.

Surrogate Mother Ditinjau Dari Segi Agama

(1) Islam, Rujukan dalam menentuakn suatu hukum perbuatan boleh dilakukan atau dilarang dalam islam adalah pertama merujuk pada Alquran, selanjutnya merujuk pada Hadist. Apabila dalam alquran dan hadist tidak diatur maka merujuk pada ijma para ulama. Praktik bayi tabung secara eksplisit tidak dijelaskan dalam alquran, namun demikian para ulama diseluruh dunia melakukan ijma dengan menghasilkan beberapa fatwa diantarnya seperti Fatwa MUI (hasil komisi fatwa tanggal 13 Juni 1979), Dewan Pimpinan Majelis Ulama Indonesia memfatwakan sebagai berikut (Febry, 2013): (a) Bayi tabung dengan sperma dan ovum dari pasangan suami isteri yang sah hukumnya mubah (boleh), sebab hak ini termasuk ikhiar berdasarkan kaidah-kaidah agama. (b) Bayi tabung dari pasangan suami-isteri dengan titipan rahim isteri yang lain (misalnya dari isteri kedua dititipkan pada isteri pertama) hukumnya haram berdasarkan kaidah Sadd az-zari'ah, sebab hal ini akan menimbulkan masalah yang rumit dalam kaitannya dengan masalah warisan (khususnya antara anak yang dilahirkan dengan ibu yang mempunyai ovum dan ibu yang mengandung kemudian melahirkannya, dan sebaliknya). (c) Bayi tabung dari sperma yang dibekukan dari suami yang telah meninggal dunia hukumnya haram berdasarkan kaidah Sadd a z-zari'ah, sebab hal ini akan menimbulkan masalah yang pelik, baik dalam kaitannya dengan penentuan nasab maupun dalam kaitannya dengan hal kewarisan. (d) Bayi tabung yang sperma dan ovumnya diambil dari selain pasangna suami isteri yang sah hukumnya haram, karena itu statusnya sama dengan hubungan kelamin antar lawan jenis di luar pernikahan yang sah (zina), dan berdasarkan kaidah Sadd az-zari'ah, yaitu untuk menghindarkan terjadinya perbuatan zina sesungguhnya. (2) Katolik dan Kristeni, Agama Kristen memandang praktik surrogate mother atau ibu pengganti untuk mendapatkan keturunan dilarang. Hal ini seperti yang disabdakan Paus Paus Pius XII pada tahun 1949 dari gereja Katolik Roma adalah tokoh agama pertama yang menanggapi secara serius masalah reproduksi buatan yang dilakukan pada manusia. Beliau berkata, "the natural law and the divine law are such that the procreation of new life may only be the fruit of marriage", yang artinya hukum alamiah dari prokreasi manusia (penghamilan) hanya boleh dilakuakan melalui perkawinan/ persetubuhan yang wajar." Dalam Kejadian 38:10 menjelaskan bahwa pembuangan sperma merupakan perbuatan yang dipandang jahat oleh Alah. Pernikahan yang dikehendaki Allah adalah pernikahan satu partner, sehingga bila dalam meperoleh keturunan melinatkan perempuan lain maka dianggap mengkhianati kekudusan pernikahan. Allah menghendaki kekudusan dalam pernikahan karena la dari kesatuan suami isteri yang la inginkan ialah keturunan ilahi, sehingga kesetiaan menjadi faktor penentu yang sangat diperlukan dalam hubungan suami isteri (Maleakhi 2: 15-16) (Nakita, 2015). (3) Hindu, Dalam program penyewaan rahim dengan prosedur-prosedur yang benar maupun rahim sebagai fungsi ekonomis sangatlah tidak etis, karena agama hindu dengan tegas menegaskan bahwa penciptaan manusia adalah hak dan kedaulatan Tuhan Meskipun dengan ilmu pengetahuan yang berkembang saat ini, manusia dapat menciptakan ciptaan yang baru tetapi, integritas sebagai manusia harus dihormati, artinya manusia harus menghormati dirinya sendiri sebagai ciptaan Tuhan yang paling luhur Berdasarkan prinsip seorang agamawan, semua hal yang bisa dilakukan, tidak selalu patut dilakukan. Sesuatu hal yang dianggap baik belum tentu benar untuk diterapkan dalam kehidupan manusia (Artila, 2017). (4) Budha, Dalam pandangan Agama Buddha, perkawinan adalah suatu pilihan dan bukan kewajiban. Artinya, seseorang dalam menjalani kehidupan ini boleh memilih hidup berumah tangga ataupun hidup sendiri. Sesungguhnya dalam agama Budha, hidup berumah tangga ataupun tidak adalah sama saja. Masalah terpenting di sini adalah kualitas kehidupannya. Apabila seseorang berniat berumah tangga, maka hendaknya ia konsekuen dan setia dengan pilihannya, melaksanakan segala tugas dan kewajibannya dengan sebaik-baiknya. Orang yang demikian ini sesungguhnya adalah seperti seorang pertapa tetapi hidup dalam rumah tangga. Sikap ini pula yang dipuji oleh Sang Buddha. Dengan demikian, inseminasi tidak diperbolehkan dalam agama budha (Artila, 2017).

\section{Kesimpulan}

Berdasarkan pembahasan diatas maka dapat diambil kesimpulan dalam upaya pelayanan medis kehamilan di luar alami antara lain sebagai berikut; Pertama, perkembangan ilmu dan teknologi kedokteran yang begitu pesat tidak diimbangi dengan ketentuan hukum yang berlaku Indonesia, sehingga menimbulkan berbagai permasalahan hukum di bidang kedokteran 
yang salah satunya surrogate mother. Kedua, perbuatan surrogate mother tidak hanya menyalahi kaidah-kaidah hukum yang berlaku di Indonesia, tetapi juga ideologi negara, yakni Pancasila. Oleh karena itu tindakan surrogate mother tidak dapat diterapkan di Indonesia.Ketiga, tindakan medik surrogate mother dapat dikategorikan sebagai perbuatan zinah, sehingga dalam mengantisipasi kekosongan hukum terhadap kasus surrogate mother di bidang hukum pidana, instrumen yang dapat diterapkan yaitu dengan menggunakan konstruksi penafsiran ekstensif. Keempat, tindakan dokter untuk melakukan pelayanan medik terhadap surrogate mother tidak hanya bertentangan etika (sumpah dokter), melainkan juga bertentangan dengan peraturan perundangundangan berlaku

\section{Daftar Pustaka}

Arikunto. 2006. Prosedur Penelitian Suatu Pendekatan Praktek. Jakarta : PT. Rineka Cipta.

Artila M. 2017. Pengaturan Hak Melanjutkan Keturunan Dalam Perjanjian Surrogacy (Sewa Rahim). Skripsi. Fakultas Hukum Universitas Mataram. file:///C:/Users/ASUS/Downloads/624076.pdf

ABS.2016.Dilema Etik Kedokteran; Surrogate Mother atau Sewa rahim. http://penamedis.blogspot.co.id/2016/01/dilema-etik-surrogate-mother-atau-sewa.html

European Centre for Law and Justice. 2012. Surrogate Motherhood: A Violation Of Human Rights. Report Presented At The Council Of Europe, Strasbourg

Febry. 2013. Surrogate Mother. http://w-afif-mufida-fk12.web.unair.ac.id/artikel_detail-711401\%20Etika\%20Kedokteran-Surrogate\%20Mother\%20(Ibu\%20Titipan).html

Nakita. 2015. Surrogate Mother (Ibu Pengganti/ Sewa Rahim).

http://nakkitanakkami.blogspot.co.id/2015/07/surrogate-mother-ibu-pengganti-sewa_25.html

Judiasih S.D*, Susilowati S Dajaan. 2017. Aspek Hukum Surrogate Mother Dalam Perspektif Hukum Indonesia. Jurnal Bina Mulia Hukum Volume 1, Nomor 2, Maret 2017 P-ISSN: 2528-7273 E-ISSN: 2540-9034

Selian M.A.H. 2107. Surrogate Mother; Tinjauan Hukum Perdata Dan ISLAM. Jurnal Yuridis Vol. 4 No. 2, Desember 2017: 131-147

Sugiyono. 2008. Metode Penelitian Kuantitatif, Kualitatif dan R \& D. Cet-5. Bandung: CV Alfabeta 